This is the peer reviewed version of the following article: Mackay, D. and Zundel, M. (2017), Recovering the Divide: A Review of Strategy and Tactics in Business and Management. International Journal of Management Reviews, 19: 175-194, which has been published in final form at https://doi.org/10.1111/ijmr.12091. This article may be used for noncommercial purposes in accordance With Wiley Terms and Conditions for selfarchiving. 


\title{
Recovering the divide: a review of strategy and tactics in business and management
}

\section{David Mackay and Mike Zundel}

\section{Accepted for publication in International Journal of Management Reviews published by Wiley-Blackwell.}

\begin{abstract}
With origins in military history, strategy and tactics is a frequently used conceptual couplet in the business and management literature. This article reviews how strategy and tactics are portrayed, identifying a dominant 'pragmatic' account of strategy as an expression of formal, planned ends achieved through the subordinate means of tactics. Pragmatic distinctions give rise to a range of well-known problems, in particular in strategy implementation stages. We suggest that some of these problems may be avoided when the strategy-tactics relationship is conceived differently and we elaborate two alternative distinctions: a sociological framing of tactics as mechanisms of resistance to formal, controlling strategies; and a processual perspective which sidesteps fixed distinctions between tactics and strategy, giving rise to more fluid interrelations between both modes. Based on a review of the business and management literature we identify key examples of each trope and conclude by drawing insights for each account on the basis of these wider discussions.
\end{abstract}

Keywords: Strategy, planning, tactics, process, sociology. 


\section{Introduction}

Strategy and tactics is a recurring conceptual couplet for both business practitioners and management academics. In this article, we review a broad cross-section of the business and management literature in order to shed new light on this age-old pairing and suggest ways of theorizing and alleviating some of the well-documented problems of the strategy-tactics distinction (Sull, et al., 2015). We look beyond the widely adopted view of tactics as a subordinate set of means by which to achieve vital strategic ends and propose that alternative sociological and processual framings of strategy and tactics can deepen our understanding and use of these concepts in organisational life.

In the business and management literature, tactics tend to be associated with lower military or organizational hierarchies, portrayed as opaque, bothersome minutiae that lack the clarity, rigour and significance of strategy formulations (Kay, et al. 2006). Where tactics are mentioned, their utility is often seen in providing mechanisms for strategic change (Nutt, 1986, 1987, 1989). For example, ‘assertive tactics' employed by CEOs may raise commitment and motivation for strategic redirection (e.g. Herman \& Nadkarni, 2014); tactics can also provide politically feasible approaches to deliver strategic aims in the context of strict regulatory frameworks (e.g. Smith, et al., 2013; Watkins, et. al., 2013); utility providers may employ lobbying tactics, including financial contributions, to exert indirect influence on regulatory agencies (Holburn, et al., 2014); tactics may be used to sway decisions of antitrust agencies in situations of mergers and acquisitions (Clougherty, 2005); or multinational companies may seek to gain legitimacy in host countries through tactical lobbying (Stevens, et al., 2015).

As political instruments, tactics are not just available to already powerful multinationals or corporations, they may also represent efficacious means for those without proper strategic power positions to survive or even prosper. For instance, Chang \& Park 
(2012: 10) cite a senior manager suggesting that the 'strange tactics' of indigenous

competitors pose greater problems than those of other rivalling multinational entrants, as they remain 'very difficult ... to predict'. A political role for tactics is further suggested in studies investigating patterns of influence inside organizations, for example where groups with less formal power but superior information may employ tactics to influence strategic decisions and thus 'correct' deficiencies in legitimate and formal systems of control (Kreutzer, et al. 2014).

Others go even further in suggesting that tactical activity may be grounded in overtly political intent to the point of being purposefully deceitful. For instance, Gaffin et al.'s (2011) identification of tactical efforts aimed at introducing 'strategic noise' in crucial periods such as CEO appointments indicates that some company boards may tactically communicate multiple corporate messages to the press simultaneously to deliberately distract and blur shareholder analysis. Similar 'stealthy or low-profile competitive tactics' have been observed in concealed attacks on rivals aimed at avoiding overt confrontation to lessen the chance for acts of retaliation (Chen \& Hambrick, 1995); or similarly dissimulating tactics such as restricting access to corporate technology and knowledge to discourse the 'predatory hiring' by competitors of key staff with valuable knowledge (Sherwood, 1990). These examples suggest that, far from being a mundane set of activities, 'tactics' are used and discussed in a variety of intricate forms. However, in stark contrast with the manifold definitions and characterizations of strategy in the literature, the structure of tactical forms of operation and the sources for tactical ideas remain conspicuously underexplored.

We tend to understand strategic intelligence in terms of affording better chances of success or survival in contexts that are prone to produce conflicts (Gray, 2006: 2). Strategy signifies a form of higher-order response in which environmental prompts are addressed with foresight, rather than with immediate instinct and where the capacity for politicking signals the triumph of reason over impulse (Freedman, 2013). Arguably first introduced into the 
business context in the wake of the game-theoretical work of von Neumann and Morgenstern (1947), 'strategy' has become a pervasive discourse (Knights and Morgan 1991) that has come to replace earlier managerial activities such as 'administration' or 'planning' (Cumming and Daellenbach, 2009). In becoming 'the master concept of contemporary times' (Carter, 2013: 1047), strategy propagates an ideology of modern, rational thought and calculation (Whittington, 1996) which has come to penetrate almost all aspects of organizational, public and private life (Bauman, 2007).

Tactics, by contrast, lack the formal and rational calculus that underpins and justifies a shared sense of how, strategically, reality can be organized and how future steps may be arranged (Cornut et al., 2012 : 24). It is therefore no surprise to find scholars suggesting that most tactical decisions are merely based on executives' 'beliefs', rather than functional relations, and that these beliefs are not the outcome of rational calculation, but primarily influenced by what others in the same social milieu say and do (Chattopadhyay, et al. 1999). Even on a practical level, disentangling strategy and tactics is a challenging task (Chaffee, 1985; Cumming and Daellenbach, 2009). Carl von Clausewitz (2007: 80) suggests that: 'Tactics and strategy are two activities that permeate one another in time and space but are nevertheless essentially different': tactics 'teaches the use of armed forces in the engagement; strategy, the use of engagements for the object of the war...' (ibid., p.74). Yet, such distinctions are easily blurred in the context of modern business engagement, for example when McNamara et al. (2008: 116) show that even far-reaching decisions, such as firm acquisitions, can be considered to be either strategic as well as tactical affairs.

The strategy/tactics relationship has long given rise to a number of reported practical problems for managers faced with the task of devising tactics that are in alignment with strategic ideals. This so-called "problem of implementation" (Churchman \& Schainblatt, 1965) indicates a schism between strategic expectations and concrete realities. This divide is frequently observed to foster social difficulties and manifest resistance between those setting 
and those impacted by strategy (de Certeau, 1988), and a perpetual sense of stress and disappointment as the practical experience of life fails to match up to idealistic, strategic expectations (Jullien, 2004a, 2007; March, 2006).

Yet, despite the vagueness about the definition of tactics and their relationship with strategy we find not only that the strategy-tactics couplet features prominently in many practitioner and academic oriented management texts (Clegg, et al., 2011; Vaara, 2010), but also that there prevails an inherent preference for all things 'strategic'. With this comes an ideology that privileges 'strategic' thinking - the abstract, long-term and explicit - when deciding which means and ends to pursue (Kay, et al., 2006). This ideological commitment to strategy has also created an entire social stratum replete with idiosyncratic routines (e.g. planning meetings, forecasting analyses), insignia (e.g. strategic plans, vision statements) and control mechanisms (e.g. audits, strategic change initiatives) that ensure that the scripts and roles of strategists remain differentiated from 'lower' and merely tactical work and personnel (Kornberger, 2013: 105). Knights and Morgan (1990), for instance, trace the genealogy of strategy in terms of the division of a military elite occupied with planning to outwit the enemy in battle and the mass of soldiers who, like pawns, may be sacrificed in pursuit of 'higher ends'. It is not difficult to identify remnants of this ideological distinction in modern cases of strategy used by elites that goes along with the loss of professional privileges in lower ranks (e.g. Herepath, 2014), or in examples of strategy discourses that undermine the power position of other organizational members (e.g. Samra-Fredericks, 2005; McCabe, 2009; Dick and Collings, 2014).

Given these problems it is helpful to understand the dominant distinction between strategic intelligence and tactical implementation not as the natural response to given environmental conditions (see also Knights and Morgan, 1991), and thereby to assume that the problems 'out there' are already of strategic and tactical orders, but that the very distinction is necessarily contingent and that it is therefore possible to conceive if it 
differently. To explore how alternative distinctions between strategy and tactics may help progress our understanding of how to work with these concepts, we present a literature review based on a search for the combined terms 'strateg*' and 'tactics'. Initially yielding more than 13,000 'hits', we review the ideas and options inherent in the 146 most relevant articles, which we read and arranged into three primary interpretations of tactics in relation to strategy: pragmatic, sociological and processual.

Our review findings allow us not only to come to a clearer characterization of tactical work but may also help address some of the practical stalemates in strategy implementation (Sull et al., 2015) by reconnecting the academic discipline of strategy with operational issues (see Nag, et al., 2007), stimulating discussion of a broader conception of managerial work as comprising strategic and tactical elements (e.g. Priem, et al, 2011). Also, examining the strategy/tactics relationship from different perspectives allows a reconsideration of tactics not merely as the mundane complement of calculative strategic initiatives but as skilful engagements whose importance and complexity is equal to that of strategy.

We begin with an outline of three conceptual backgrounds described above even though, in our inquiry, these perspectives emerged as a product of our review of the business and management literature which populates much of the second half of this paper. Finally, we discuss how our findings may contribute to a richer understanding and practical efficacy of the strategy-tactics couplet.

\section{Conceptual background: pragmatic, sociological and processual understandings of the strategy-tactics relationship}

We have already alluded to some of these consequences of the separation of strategy and tactics, for instance that particular consequentialist forms of argument with clear meansends logics are given preference over less formal and explicit claims (March, 2003), or in form of the creation of a specific class of managerial (and military) elites who, in making strategy, exert control over those dealing merely with tactics. As the wider effects of these 
dominant strategy discourses have already been explored elsewhere (e.g., Knights \& Morgan, 1991; Carter, 2013), our review focuses on alternative ways in which strategy/tactics distinctions are drawn in order to elaborate the possibilities for understanding the relationship between these concepts in different ways.

For this we begin with the most common type of distinction which we call 'pragmatic'. Here we find separations of the 'formulation' of strategic ends from tactical means of 'implementation'; higher geographical or logical strategic abstractions from local and specific tactical concerns; and long term strategic considerations from immediate tactical actions. A smaller set of literature which we call 'sociological' focuses on issues of power, control and resistance - concerns which are highly pertinent for organization theory, for instance in the context of institutional pressures and organizational resistance (Oliver, 1991). Here, tactics represent a sphere of possible reactions to positions of power (e.g. Scott, 1985, 1998; Jacobs, 1993). A third perspective of strategy and tactics relates to approaches we term 'processual', suggesting that the very distinction between both realms can be the source for subsequent confusions and problems. The military theorist von Clausewitz already was careful to emphasize that, whilst important for education, military history and theory could only limitedly inform behaviour on the battlefield which 'lives and reacts' with its environment and situation-specific demands (see also Gray, 2006: 35; Jullien, 2004a: 14). Intrigued by the intricacies of changing situational contexts, processual approaches such as Jullien's (2004b) study of ancient Chinese warfare or Chia and Holt's (2009) 'strategy without design' elaborate the radical claim that it is possible to avoid a strategy-tactics split altogether. We continue with an outline of these three perspectives before, informed by these ideas, we turn to a review of the business and management literature.

\section{Pragmatic distinctions}

The dominant portrayal of the strategy and tactics relationship is 'pragmatic'. It is grounded in the idea that strategy concerns the formulation of an integrative long-term, 
abstract and broad vision, which is to be implemented by the localised mechanisms of tactics. This portrayal now dominates academic (strategic) management articles, but we can find its roots in the study of armed conflict. Military historian Freedman (2013: 5) for example argues that strategic intelligence "evolved through interactions in a complex social environment as much as from the demands of survival in a harsh physical environment". Being strategic is a pragmatic quality as planning ahead and cooperating with others - rather than merely tactically and individually reacting to specific situations as they come - proves advantageous in struggles for survival. For Freedman (2013), the characteristic feature of strategy is that it affords successful responses in situations that invite conflict - whether in a group of primates or, with much higher degrees of complexity, in the battlefield or in competitive situations.

One key historical example illustrates a nearly complete (pragmatic) detachment of strategic intelligence from tactics: the deliberations of the RAND corporation in the US (Trachtenberg, 1989: 303). With the advent of nuclear weapons, the intricate 'tactical' details of warfare that had hitherto occupied military command suddenly became insignificant in relation to purely strategic considerations, in particular to the game-theoretical play of nuclear deterrents and the double-bind of defence capability and economic cost. The strategy of the Cold War therefore shifted from the question of how to better or more quickly attack an enemy to the question of funding (Trachtenberg 1989: 311). This example depicts a near complete separation of strategy and military tactics by which political and economic strategies are employed to avoid the particulars of military engagement. It signifies the victory of reason over impulse, as it requires the insight that war, albeit horrible, is sometimes appropriate but that its violence has to be planned and controlled (von Clausewitz, 2007) and as any strategy leading to national suicide (as in the case of actual nuclear engagement) would by no means be controlled. The key insight of such strategy was that appropriate military tactics had become improbable if not obsolete, but in any case avoidable (non)options in strategic calculations (Trachtenberg, 1989: 304). 
Whilst the conditions leading to this particular example of an all-embracing concern for strategy may be idiosyncratic to the particular conditions of the Cold War period, we can trace similar sentiments in the business literature on strategy. An influential example is provided by the work of Porter (1996: 78), for whom strategy is about deliberation; a matter of 'discipline and continuity' when establishing and preserving unique forms of operation. Porter's work echoes the ideal that in an era of heightened strategic intelligence, operational matters are necessary but ultimately of secondary regard. From this perspective, strategists must develop panoramic vision, leaving middle and lower organizational ranks to merely execute the details of strategic ideas. It is thus mainly in studies of lower ranking managers that we find explorations of tactical engagements, such as Rouleau's (2005) illustration of 'middle managers' tactics when engaging with a company's clients.

The pragmatic view of the strategy-tactics distinction therefore has its origin in the overarching idea that rational calculations of long-ranging means-ends relations are more effective than immediate reactions. Where strategic intelligence is considered superior tactical concerns can be delegated to lower ranks or, in the case of RAND, may be dispensed with altogether.

Sociological distinctions: power and resistance

The assumed superiority of strategy over tactics is fundamentally upended in a second perspective which we term 'sociological', which questions social positions and how these affect or constrict human behaviour. A renowned example of this perspective is the ethnologist Michel de Certeau's (1988) juxtaposition of strategy and tactics, where the former signifies "the calculation (or manipulation) of power relationships that becomes possible as soon as a subject with will and power ... can be isolated" (ibid, p. 35). For Certeau, strategy is the preserve of those in formal positions; those occupying 'proper places', either in military terrains, in business contexts, or in society. From these secure positions it is possible to manipulate those who do not occupy positions of power, and for whom only tactics are 
available. Lacking the formal power to change the parameters that define their situation, those out with the elite may cope through ingenious, cunning, or deceptive responses performed autonomously 'on the wing' (ibid, p. xvii; p.37). These responses circumscribe what Certeau refers to as tactics.

From this sociological perspective, the question is not so much one of the superiority of strategic actions (even though these reflect the will of those in superior positions), but of reciprocity between strategic and tactical ways of operating: the strategic imposing a context in which the need for (and the potential efficacy of) tactical actions arises. Those governed by strategies are not merely passive recipients of others' instructions, but they are capable of resistance, creatively ignoring, manipulating or misapplying official dictates (Scott, 1998). The more elaborate and imposing the strategic calculations of a state, corporate headquarters, or local management become, that is, the more powerful these groups are, the greater chance of contradictions, grey areas, or blind spots that invite 'tactical' exploitation. Tactics serve to continually rebalance the power relations as continually diverse sources take part in the dynamic organization of a particular social situation and the negotiation positions (McInlay, et al., 2010),

The sociological view indicates that strategy is not merely a neutral response to environmental demands, but that the capacity for strategic directives is provided by the occupation of a position of power. Although strategy and control can not be separated (Knights and Morgan, 1991), those without such positions are neither hapless nor passive. Tactics at once signify the precariousness of the lack of strategic places as well as the potential to find and exploit subtle and often temporary means of resistance to measurement and control systems (Scott, 1998), and thus the insight that power cannot forever be singularly and centrally held (McInlay, et al., 2010: 1019).

This sociological reading of strategy and tactics runs counter to the preference for abstraction and formulation that typically accompanies the pragmatic distinctions previously 
outlined. From the sociological perspective, tactics refer to the activities taken by individuals striving to profit from, evade, resist, or simply cope with attempts at creating strategic order imposed by those with formal authority. For Certeau (1988), strategy and tactics are merely different kinds of engagements. Tactics emerge as a response to the formal powers of strategies so that both strategy and tactics depend upon one another like two sides of a single fracture.

\section{Processual non-distinction}

The sociological perspective recasts tactics from an inferior, less intelligent class of actions to an equal counterpart in struggles of control and resistance. A further nascent perspective in the literature pushes this emancipation even further by suggesting that a strategic mode of engagement is not so much an intellectual advantage but a practical hindrance in comparison to a tactical mode of operating. This 'process' perspective suggests that the isolation of historical events as a basis of calculation, prediction and action of strategic moves is becoming increasingly useless in the face of modern complexity, technological development, and worldwide integration (see Valery, 1962: 16; Gray, 2006: 26, 76). Heuristics based on the past often lead to misspecifications of current situations, producing disadvantageous results (March, 2006: 203). Moreover, as Clausewitz (2007: 117) forewarned, not only are historical patterns of lesser and lesser relevance, we must also be careful with information about the present. His dictum 'most intelligence is false' precedes later 'bounded rationality-like arguments' (Augier \& Guo, 2012: 434) and suggests that where information is inherently untrustworthy, the pursuit of warfare cannot be subject to calculative reason alone but requires intellectual activity that 'leaves the field of the exact sciences and becomes 'an art in the broadest meaning of the term' (Clausewitz, 2007: 585).

Contributors to what we call 'processual' approaches see these problems primarily as products of the very distinction between strategy and tactics which imposes significant problems for those tasked with aligning both sides of this distinction. Processual approaches 
are animated by the idea that strategies and tactics refer to actions with indirect and direct effects respectively, and what we might refer to as a strategy is nothing more than the continued tactical engagement where affairs are forever re-arranged without imposition of arrest and control (Chia and Holt, 2009; Munro, 2005). Here, the strategist abandons her 'iron will' (Clausewitz, 2007; Jullien, 2004a: 13) and the virtues of 'discipline and continuity' (Porter, 1996), instead embracing the non-heroic role of keeping options open and protecting a capacity for responding to the world.

For example, Jullien (2000, 2004a, 2004b) elaborates an intellectual background for a processual approach through studies of Chinese military conduct, poetry, art and aesthetics grounded in 'blandness'. Blandness indicates "inner detachment regarding all particular motifs and all possible motivations" so as to be able to continually redraw lines and preserve responsiveness to unfolding situations (Jullien 2004a: 37). This blandness is best achieved by a continuing evaluation of both tactical and strategic implications of activity - doing enough to deal with immediate requirements whilst striving to preserve a future capacity to act. From this perspective, the strategy-tactics relationship draws attention to the indirect and direct consequences of our actions, and continuing trade-offs between addressing immediate concerns and preserving our capacity for taking action in the future.

Table 1 summarises the conceptual backgrounds to the three above perspectives and preempts findings of our subsequent review of the business and management literature addressing the strategy and tactics couplet. To enable a discussion of the implications of the different distinctions represented in table 1, we will now further unpack each perspective in turn through a structured review of the business and management literature.

\section{[Insert TABLE 1 about here]}




\section{Method}

Based on this elaboration of the backgrounds of three alternative distinctions between strategy and tactics we can turn to our review of the business and management literature which gave rise to our identification of these three perspectives. This review was complicated by the sheer volume of articles on strategy and tactics and, furthermore, by various complementary concepts. One example is the burgeoning literature on 'strategy as practice' (e.g. Johnson, et al., 2008), which appears to deal with similar concerns about the relationship between planning and doing. However, not only has this literature already been subject to a number of specific reviews (e.g. Jarzabkowski and Spee, 2009; Vaara and Whittington , 2012), we also found that the term 'practice' was frequently used as a synonym for strategy, for instance where strategizing is described as a practice (Johnson, et al., 2008) or, in the more sociological works of Certeau (1988) and Scott (1998), where 'practice' denotes an umbrella concept encompassing both strategic and tactical behaviours. To retain the sharpness and inherent oppositional tension of the conceptual couplet we therefore decided to keep narrowly focused on the terms 'strategy' and 'tactics', not including the term 'practice'. We began with systematic search for the combined keywords in business and management literature. Systematic reviews provide an audit trail and sense for the readers as to how material for inclusion in a review was identified and analysed (Lee, 2009; Tranfield, et al., 2003).

Furthermore, given our concern for both strategy and tactics, we felt it important to search for contributions that lie outside of the 'proper places' of high profile journals and citation lists. A keyword search for strategy and tactics across a large number of journals therefore allowed us to identify papers at the fringes which have not achieved 'proper strategic' status. More generally, systematic reviews have been acknowledged to be relevant to scientific empirical syntheses (Rousseau, et al., 2008), offering the potential to develop high quality, impactful contributions in management studies (Macpherson \& Jones, 2010). 
Our reviewing activity was structured around the key research questions, "In what ways are strategy and tactics depicted as related concepts in the literature?" and "What implications can be derived from the nature of the depictions detected?" We undertook an electronic database search to first identify potentially relevant papers. We searched directly on the publishing house databases for journals maintained by Elsevier, Emerald, Sage, Wiley and Taylor and Francis, and used the integrative search engines ABI and Business Source Complete for all others. We then elected to search all journals in the SSCI "management" listing for all accepted submissions up until the 1st August 2013 (no lower date limit applied). The search terms adopted were "strateg*" AND "tactic*" in title and/or abstract only, in order to identify variants of strategy and tactics such as strategic, strategically, tactical, tactically etc. This criteria was adopted with the intention of identifying papers in which the relationship between strategic and tactical matters, in whatever interpretation adopted by the authors, was sufficiently prominent in a paper's content as to merit inclusion in the opening summary. This was an important practical limitation to impose as searching for the terms strategy and tactics in all document text currently yields over 13,000 returns.

\section{[Insert Figure 1 about here]}

Figure 1 summarises the process we followed when selecting papers on which to base our review. Applying the search criteria returned 654 potentially relevant papers across 172 journals. We then read the abstracts of all papers in order to identify articles in which "strategy" and "tactics" (and variants thereof) were used in relation to each other. Eliminating papers where strategy and tactics were not sufficiently related reduced the number of articles for consideration to 146 . We then reviewed these papers in full, with responses to the initial research questions captured in electronic form. These electronic notes were then further analysed through tabulation and discussion between authors in order to identify the patterns and findings presented in this paper. Following Lee (2009), as our review progressed we also included further sources (as listed in this paper's references) that were referenced by the 
papers reviewed or which, more recently, had cited key contributions, in order to deepen our understanding of the emergent portrayals of strategy and tactics.

\section{Literature review}

In this section, we seek to describe detailed arguments, assumptions and implications associated with the pragmatic, sociological and processual perspectives of the distinction and relationship between strategy and tactics.

\section{Pragmatic understandings of strategy and tactics}

The majority of papers we reviewed (102 out of 146) can be classified into what we have termed 'pragmatic' understandings of the relationship between strategy and tactics either in terms of strategic formulation versus tactical implementation; general strategy versus local tactics; or long term strategic versus short term tactical horizons. We discuss each in turn.

Pragmatic: formulation vs. implementation

Most frequently we found strategy associated with direction setting, in particular as formulation of plans, whereas tactics was equated to actions required to implement strategic ideas in organizational practice (e.g. Bell \& Keusch, 1976; Huntsman, 1994; Nutt, 1986, 1999; Slevin \& Pinto, 1987). This formulation-implementation distinction is frequently portrayed as a distinction between thought and action where strategy is associated with rational analytical calculations, while tactical actions are seen to be more mechanical and basic (Hultink, Griffin, Hart, \& Robben, 1997; Lant \& Hewlin, 2002, Kolb, 1983; Sagie \& Koslowsky, 1994, Sodhi, 2003). The formulation-implementation distinction also engenders a time sequence and causal, means-ends relationship whereby strategic aims are linked with wider organizational goals while tactics provide specific means by which these ends can be achieved (e.g. Miller \& Ireland, 2005; Nutt, 1998a; Pinto \& Prescott, 1990; Sagie \& Koslowsky, 1994). 
Most authors drawing on formulation-implementation distinctions depict an implicit or explicit preference for strategic concerns over tactical means. For example, there is a frequently made suggestion that strategies ought to come first while tactics are set according to the outcomes of strategic evaluation, decision-making and planning (Appelbaum, Everard, \& Hung, 1999; Bell \& Keusch, 1976; Nutt, 1987, 1989). For Casadesus-Masanell \& Ricart (2010: 202, our emphasis) tactics are “...the residual choices open to a firm" after a strategy has been selected while others propose that strategists should specify boundaries or structures in order to constrain tactical work, lest they become deviations from existing strategic goals (Giles, 1991; Ronchi, 1980). Preference for 'strategic' concerns is also visible in the suggestion, by a number of authors, that tactical problems can be avoided by undertaking 'better' measurement. Rather than championing potential improvements in an organization's tactics, the focus lies on improved analysis and calculation on the strategic level in order to make more precise guiding strategies (Nutt, 2008; Peters, 1993; Sodhi, 2003), or by including contingencies into strategic plans to accommodate a range of environmental circumstances and thus pre-empt problems on the tactical level (Casadesus-Masanell \& Ricart, 2010).

One important variation of the formulation-implementation distinction comes in form of cyclical pragmatic models incorporating notions of feedback. Often drawing on Mintzberg and Waters's (1985) articulation of a continuum from deliberate to emergent strategy, scholars have emphasized that paying attention to issues on the tactical level may facilitate reflections on strategic formulations, and vice versa (Ählström \& Sjöström, 2005; Jantsch, 1968; Sull, 2007, Sull et al, 2015). Such cyclical models go some way towards acknowledging feedback processes between abstract strategy formulations and insights travelling from the bottom up (Eisenhardt, 1990; Lax \& Sebenius, 2012). In cyclical models, environmental complexity and uncertainty are addressed through tighter coupling and interlocking of strategic and tactical activities (Dinwoodie, Tuck, Knowles, Benhin, \& Sansom, 2012; Sull, 2007); commitment to regular sampling of the environment and adjustment to contingently revise; and 'fit' of strategy and tactics based on practical 
experience (Dahlander \& Magnusson, 2008; Ghemawat \& Levinthal, 2008; Harris, 2000; Pech \& Slade, 2003, Sull et al, 2015).

Pragmatic: General vs. specific

A second iteration of the pragmatic distinction plays out along a continuum from general strategic to specific relevance. This dimension can be understood in terms of degree of abstraction involved in strategy work, which often includes probabilistic reasoning based on analysis of a highly complex organisational environment (Porter, 1996). By contrast, tactics are seen to concern practical theorising with the aim of finding context specific workable solutions and quick reactions often grounded in individual interpretations of reality (e.g. Dibb \& Simkin, 1993; Gibson, 1966; Jantsch, 1968; Massetti \& Zmud, 1996). Tactics lack such abstract and general qualities, their efficacy being contingent upon specific circumstances (Nollet, Rebolledo, \& Popel, 2012; Nutt, 1993, 1998a, 1998b).

More frequently, the general-specific distinction is elaborated in terms of spatial scope, ranging from broad and systematic decision patterns with far-reaching implications to more fragmented, functional and local tactical responses (Bacharach, Bamberger, \& McKinney, 2000; Clarke \& Varma, 1999; Gibson, 1966; Gronroos, 1996; Guiltinan, 1999; Harris, 2000;). Here, strategy corresponds with the sphere of influence inhabited by organizational elites holding organization-wide responsibilities (Knights and Morgan, 1991), while tactics remain the purview of departmental managers ranging down to the shop-floor (Donaldson, 1972; Eisenhardt, 1989, 1990; Struckman \& Yammarino, 2003). It is therefore not surprising to find many contributions resorting to seemingly commonsensical distinctions of the sort: It is called 'strategy' when it is done by senior managers and we deal with 'tactics' if it happens on local sites, in departments and teams (Mahmoud, 1975; Meijboom \& Obel, 2007; Rangan \& Jaikumar, 1991). 
However, this pragmatic shortcut is frequently upset, in particular as strategic and tactical considerations are increasingly ascribed to a wide range of actors, from organizations, governments, industries, and nations to individuals - all of whom are described as 'having' and 'using' strategies in a broad range of contexts (see Bauman, 2007). As we may expect, strategies are frequently associated with corporate or organisational level activities, but even here we find descriptions of functional tactics such as product launches (Easingwood \& Harrington, 2002; Guiltinan, 1999); political tactics (Barron, 2010; Schuler, Rehbein, \& Cramer, 2002); use of social media (Sinclaire \& Vogus, 2011) management of suppliers (Nollet, et al., 2012); expanding operations (Lilien \& Rao, 1979); or in response to unexpected events, such as operational crises (Pauchant, Mitroff, \& Ventolo, 1992). Some papers even address institutional level strategy and tactics. For example, in a paper couched in contemporary strategic management terms, Carmeli and Markman (2011) draw on historical data to identify high-level generic strategies (capture and governance) and associated tactical approaches (saving power, building a stronghold base, isolating, weakening and developing forward outposts) to analyse the fortunes of Ancient Rome. Other intra-organizational studies have addressed the strategy and tactics of third sector and private organizational partnerships (Ählström \& Sjöström, 2005) and social movements seeking to exert institutional pressure (Yaziji \& Doh, 2013). The hierarchical distinction is blurred even further in accounts such as Ramanath and Ebrahim's (2010), who identify NGOs' strategies of 'confrontation' or 'cooperation', each consisting of a variety of tactics, such as 'street protests' or 'budgeting', respectively.

Moving in the opposite hierarchical direction, strategy-tactics distinctions equally pertain to the activities of organisational units, for instance the strategy and tactics of marketing (Dibb \& Simkin, 1993), advertising (Doyle, 1977), supply chain management (Rangan \& Jaikumar, 1991), product management (Greenley, 1983), project management (Slevin \& Pinto, 1987), general research and development (Gibson, 1966), or human resource management (Baker III \& Feldman, 1991). Even on the level of individuals we find a 
substantial literature detailing personal career strategies. Here, tactics can refer to attempts at influencing personal progression (Judge \& Bretz, 1994; Keys \& Case, 1990; Tepper, 1995) or to boundary management activities for those providing peer support (Bacharach, et al., 2000).

\section{Pragmatic: Long vs. short-term horizon}

A third iteration of the pragmatic distinction dimension is in terms of time. Strategy is presented as addressing questions of the distant future, in comparison to the short-term concerns of tactics (Giles, 1991; Greenley, 1983; Huntsman, 1994; Lant \& Hewlin, 2002; Stonebraker \& Afifi, 2004). There is, however, little consistency in the literature as to what counts as long or short term and specific suggestions, where we find them, are conspicuously arbitrary, such as Huntsman's (1994) taxonomy equating strategy with plans of five years and tactics to related three year targets.

Long and short-term distinctions are further complicated by suggestions of different kinds of time entailed in strategic and tactical modes of engagement. Linear notions of time typically underlie the possibility of strategic scenarios and planning (e.g. Donaldson, 1972) as events can be plotted in abstract, causal terms, and then freely (re-)arranged through thought experiments such as scenario planning approaches. 'Richer' notions of time, on the other hand, suggest that time cannot, in any simple way, be reduced into critical paths (Connelly, Tihanyi, Certo, \& Hitt, 2010; La Londe \& Headen, 1971). Both tactical (see, for instance Hjorth, 2007) as well as strategic processes therefore not only pertain to the linear timescales of calendars and project plans, but also in time, that is within the lived experience of past, present and future (Bakken, et al., 2013).

\section{Critiques of pragmatic conceptions of the strategy-tactics relationship}

Above we have described three iterations of the predominant pragmatic distinction between strategy and tactics: formulation vs. implementation, general vs. specific; and longvs. short-term horizon. Despite a large number of publications based on pragmatic 
differentiations of strategic from tactical work, we found that the actual distinctions between both modes are blurry and inconsistent. What is more, with some exceptions (e.g. Ählström \& Sjöström, 2005; Jantsch, 1968; Sull, 2007; Hjorth, 2007) we found that most papers explicitly or implicitly advocated strategy as being of greater importance than tactics, with tactics frequently being portrayed as the problematic detail of rational strategic plans (e.g. Churchman\& Schainblatt, 1965; Anderson and Hoffman, 1978; Nutt, 1983, 1986; Hambrick \& Cannella, Jr, 1989). Some authors speculated as to how tactical work may be improved by modelling the strategic mode of operating in day-to-day situations to attain a form of tactics that is more integrative, externally aware, disciplined and continuous for the attainment of objectives, particularly revenue generation (e.g. Cross, Higbie, \& Cross, 2009; Kimes \& Singh, 2009; Lake, 2004; Okumus, 2004). However, even scholars calling for betterintegrated strategy research that builds understanding of how firms tactically react to changing conditions remained careful to disassociate themselves from 'day-to-day operating decisions' (Priem, et al., 2011: 472).

We also found numerous reports suggesting that the vagueness of pragmatic distinctions between strategy and tactics leads to concrete practical problems for practitioners (Angell, 1990; Giles, 1991; Goldman, 2001) when faced with the task of aligning operational tactics with strategic directives (Takala, et al., 2006). In particular long vs. short-term distinctions bring difficulties. Clausewitz (2007) already elaborated the problem of 'frictions', which emerge in in the time-gaps between planning and acting. Frictions denote the outcome of random changes in the environment over time (Paquette, 1991) as well as recursive changes that occur when strategic initiatives provoke social and political reactions from those affected by mooted activity (Nutt, 1986, 1989). Even seemingly benign interventions aimed at generating alignment of strategic and tactical goals such as incentive scheme design (Micheli \& Manzoni, 2010) and performance measurement reporting (Huntsmann, 1994) have the propensity to generate distorting effects in self-organising contexts, for instance when individuals adopt personal value maximisation approaches (Schein, 1979). This may lead to 
the paradoxical situation that increasingly detailed strategic designs of control (aimed at managing the effects of self-organisation) may become sources of additional complexity which generate and intensify feedback processes (March, 2006) - adding further friction and thus increasing strategic uncertainty in turn.

Relatedly, where strategies are distinguished from tactics in terms of their broader scope, it has been found that strategic and tactical interests do not always cohere. Local and immediate tactical gains may run counter to more general, longer term strategic intentions (Angell, 1990; Lax \& Sebenius, 2012), for instance when short term measures to boost share prices destroy shareholder value over a longer duration (Connelly, et al., 2010; Markides \& Berg, 1992). Knights and Morgan (1990) also indicate that strategic aims tend to benefit those at the upper end of the social stratum, whilst justifying the demand of sacrifices from others. Some have therefore pointed to the prevalence of vested interests involved in strategy and tactics (Gray \& Ariss, 1985; Schein, 1979), making strategic work subject to the "vagaries" and "deviousness" of people at all levels of the organisation (Harris, 2000: 870). Others have highlighted the incommensurable needs for continued updates of strategic representations (Clarke \& Varma, 1999; Sull, 2007) and the inevitable time lags and inertia involved in agreeing changes to strategy in organizations (Harris, 2000; Sull et al., 2015). In recognition of the impossibility of strategies pre-empting future events, tactics have also been portrayed to act as necessary correctives; a form of realized direction correction refreshed on a more frequent basis (Raturi, et al., 1990), or as a mechanism to account for errors or risks in strategic plans (Bush \& Gelb, 2005; Ghemawat \& Levinthal, 2008).

Problems also accrue when strategy and tactics are distinguished in terms of general reach vs. local relevance. As we have outlined above, both strategic and tactical capabilities are frequently ascribed to various units of analysis, ranging from individuals to organizations, industries and nations, thus making any consistent strategy-tactics distinction an unlikely possibility. Many authors also note that practical problems are an inevitable consequence of 
attempts at strategic abstraction in the messy, fluid, vague, highly complex and not fully knowable organizational context (Dahlander \& Magnusson, 2008; Kolb, 1983; Lax \& Sebenius, 2012; Pauchant, et al., 1992; Sull, 2007). Against this backdrop, tools and techniques of strategic modelling are argued to foster often unacknowledged gaps between their representations and the realities of organisational life, but are frequently found to fall short of representing the context examined by strategists with sufficient depth, scope and dynamism required to create reliable platforms for prescriptive decision making (Gibson, 1966; Lant \& Hewlin, 2002; Lueger, Sandner, Meyer, \& Hammerschmid, 2005).

As a consequence of conceptual as well as practical grey areas of these pragmatic distinctions, labels of 'strategy' and 'tactics' are used quite freely based on situational suitability (Bacharach, et al., 1995) and it sometimes seems that one person's strategy may be another person's tactics (Peters, 1993). Some have therefore called for an academic agenda towards greater clarity in the definition of the concepts of strategic management (e.g. Casadesus-Masanell \& Ricart, 2010), while others are developing tools that approach tactical questions in the same scientifically analytical fashion that is characteristic of strategy, for instance via decision trees for tactical selection, increased managerial intervention, or SMART-er tactical direction setting (e.g. Giles, 1991; Nutt, 1989, 1999, 2002; Peters, 1993).

Such efforts to create 'more strategic' ways of instigating tactics indicates the mainstream preference for a strategic mode; that is, for rational thought, clear-cut boundaries and neat categories of thought, coupled with a dislike for messy and unclear 'stuff' (Cooper, 1986; Nussbaum, 1986: 260). Yet, this begs the question of whether this may exacerbate rather than resolve the problem of implementation by further reifying the distinction and onesided preference of a strategic mode of engagement over a tactical one when, arguably, both ultimately belong together. 


\section{Sociological understandings of strategy and tactics: the (re-)production of formal order}

The dominant pragmatic portrayal of strategic ends and tactical means is markedly different to a sociologically influenced perspective in the management literature dealing with tactics not as a means to serve strategic ends, but as a creative response to political processes of those in power in any given situation. This literature pays heed to how strategic positions wax and wane in relationship with the actions of those (dis)affected by strategic power. For example, in what has been termed the 'principal agent problem', the imposition of an organisational strategy reflects an attempt at controlling and making transparent the actions of managers for a group of owners who are themselves detached from the organisation's machinations 'down below' (Buskirk, 1976; Gray \& Ariss, 1985). Attempting to maintain alignment of managerial activities by imposing a dominant strategic framework resembles the initiatives of city planners in positions of formal authority who turn to mechanisms of surveillance and punitive action to control ground-level activities from above (Certeau, 1988; Scott, 1990; Suominen \& Mantere, 2010). However, in distinction to viewing tactics as a means of implementing such formal (strategic) orders, they can be understood as a way of empowering those who are being controlled when they enact creative responses to mediate, transform or resist imposed structures.

Tactics can therefore exploit the 'frictions' inherent in strategic plans, for instance by drawing on narratives from outside the organisation to resist workplace change (Cutcher, 2009) or when employing negotiation tactics to redefine formal structures (Kharbanda \& Stallworthy, 1991). Harris (2000: 862) identifies a range of tactics that include "laissez-faire, external assistance, internal training, coalition formation, structural change and scaremongering" employed by managers to evade the effects of restrictive planning or deal with increased pressures to plan.

Tactical responses extend beyond reactions to strategic surveillance and control efforts, and may also include covert creative exploitation of overt strategic frameworks. In 
acts of corruption, protest or resistance, tactics can represent amoral responses to dominant ideologies, moral frames of reference or sometimes even legality (Anand, et al., 2005; Schein, 1979; Siegel, 2009). Similarly, they can involve active or passive resistance to strategic ideals and associated artefacts (procedures, policies, resource allocation decisions, etc.) that dictate acceptable courses of action for those operating within an organisation (Hjorth, 2005). Suominen and Mantere (2010), for instance, detail instances of what they call 'playful strategy usage', which is in most parts quite cynical and critical towards more formal prescriptions of strategy. Such tactics can be generally useful, as unsettling and playful actions can act as a change stimulus in the face of a dominant ideology (Elsbach \& Sutton, 1992), for instance, when managers “... use and appropriate the strategy discourse skilfully for their own purposes to resist and alternate it, while at the same time articulate and talk in ways that do not directly confront the dominant discursive regime" (Suominen and Mantere, 2010: 239).

These examples neither portray tactics as thoughtless implementation means for strategic ideas nor as the product of objective and formal analysis. Instead, they point to the potential for savvy tactical responses as key enablers of the attainment of beneficial outcomes against the odds of a dominant strategic context (Page, 2010). Tactics can provide momentary efficacy for individuals, in a very functional way doing 'whatever works' (Buskirk, 1976), similar to descriptions of organizational bricoleurs (e.g. Baker, Miner, \& Eesley 2003; Gabriel 2002). While the public discourse of formal strategy is there for all to see in strategy documents and plans, tactics can remain opaque or lack transparency with regards to motive (Cutcher, 2009; Denis, et. al., 1996; Sonenshein, 2006). The potentially disruptive, equalizing or liberating influence of tactical responses is reflected in contributions proposing that strategy is inherently political and that strategist ought to anticipate the tactical responses of those affected (e.g. Vredenburgh \& Maurer, 1984). Pfeffer (1992) equally highlights the need for political awareness in strategy work and highlights the potential stalemates created when 
an organization solely relies on hierarchical authority when trying to implement its strategic ideas (c.f. Lovell 1993).

Albeit consisting of far fewer contributions, the sociological perspective gives rise to an important rebalancing of the perceived importance of tactical engagement. In freeing tactics from pragmatic means-ends continuums (from general to specific, long to short term; or thought and action), we find tactics portrayed as an important and complex reactive counterpart to strategy, requiring much skill and, if done well, yielding efficacious results. In eschewing consequential logics, calculation, and clear distinctions for a much messier, engaged, and practical way of operating, the sociological perspective of tactics in relation to strategy also challenges the disproportionate focus on strategy at the expense of tactics, and the value of organizational separation and the frequent preference for those who 'think' over those who 'act'. A practical upshot of the sociological perspective is the insight that neglecting the intricacies of tactical work when trying to understand organizations or formulate strategic plans makes strategists susceptible to tactical manipulation and resistance.

\section{Processual (in)distinction between strategy and tactics}

The recovery of the importance and intricacies of tactical engagements is elaborated further in in what we call 'processual' contributions which problematize the very distinction between strategy and tactics. Deliberately blurring or avoiding rigid distinctions between strategic modes of engagement from tactical ones is suggested to afford a degree of 'resilience' to the problems associated with traditional differentiations between both realms (Hamel \& Välikangas, 2003). Drawing on the work of T.E. Lawrence, Munro $(2005,2010)$ articulates 'nomadic strategy' as a descriptor for such a fluid in-distinction between strategy and tactics. Instead of attempting to control the environment by means of plans, forecasts, or scenarios, the processual strategist remains on the level of everyday activity and "in step" with ever-unfolding reality (Jullien, 2004: 78). Similarly, the nomad finds herself continually on the move, muddling her way through landscapes to which she is finely attuned, exploiting 
the temporary advantages that emerge without settling in any one location. Resisting distinctions between strategic and tactical concerns requires an iterative process ".. based on constant questioning, experimenting, reflecting, debugging and retesting" (Isenberg, 1987: 96) without fixing long term plans or striving for anything more 'proper' (Chia \& Holt, 2009).

The potential efficacy of such approaches is exemplified in the success of exceptional organizations such as WL Gore whose revolutionary non-hierarchical and distributed style reflects a blurring between strategic and tactical concerns (Hamel, 2007, 2012). Other examples include Baker, et al.'s (2003) study of three start-up firms who utilize a series of tactical improvisations and, despite the owners' 'strategy' glossing, remain successful in absence of general, explicit and longitudinal ideals. Similarly, Kolb (1983) describes how sustained tactics in labour mediation processes represent a strategic modus operandi, as turf wars that come with fixed and entrenched negotiating positions are avoided by repetitively getting parties to meet and (re)negotiate their claims. A further example is provided by Tardif, et al., (2010), who show how a manufacturer of agricultural machinery profited from adopting a tactical focus on taking small steps and close coupling with the environment, continually adjusting their management approach to local circumstances without any strategic fixing of the content or direction of these changes.

The avoidance of fixed positions runs very much against the grain of the dominant pragmatic perspective in which decisive and heroic managerial action is realised through resource commitment and steadfastness when making 'strategic choices' (e.g. Child, 1997). Yet, even within the notionally pragmatic mainstream literature, we can regularly detect glimpses of processual thinking when it comes to preserving speed of movement when taking decisions (Eisenhardt 1989, 1990) or fostering abilities to react to changing circumstances in a concrete and fleeting tactical manner (Isenberg, 1987; Rock, 1987). Others have suggested that the very stipulation of decisive goals can be debilitating while freer 'participative 
techniques' may lead to 'better strategies and tactics' (Durham et al., 1997: 227). In a dynamic, networked society (Bauman, 2007), where official information and formal structures are increasingly disrupted by information warfare from actors such as governments, hackers, lobbyists and paid bloggers, less and less trust can be placed in proper systems to safeguard social, technological and biological cohesion from disintegration and disorganization (Munro, 2005, 2010). In acknowledging that "with every revelation comes concealment and with every seemingly objective claim comes an unstated and unacknowledged personal and collective emotional involvement" (Nonaka, et al., 2014: 367) a processual perspective explores strategy and tactics within the frame of a modus operandi that thrives on preserving and exploiting openness in the context of an ever-shifting world (Hjorth, 2005; Westphal \& Bednar, 2008). These concerns hark back to insights by military historians such as Gray (2006: 77) for whom there can be no mechanical/technological panacea to the task of warfare which instead requires practical wisdom, making strategy as a practical subject whose efficacy lies in its execution.

Whilst being the least populated of our identified literature subsets, the processual perspective most directly questions the utility of the strategy-tactics distinction by elaborating a possible alternative which, consequently, also sidesteps problems of 'implementation' whilst minimizing the scope for others' tactically political responses.

\section{Discussion and conclusions}

Our review has identified that most contributions to this literature draw pragmatic distinctions between strategy and tactics. These are often rooted in historical military hierarchies, associating strategic intelligence with rationality and abstraction at the expense of merely tactically concrete and non-calculative modes of operation. We contrasted this dominant perspective with two alternative ways of conceiving the strategy-tactics relationship. 'Sociologically', tactics present a mode of responding to strategic impositions, often with the aim of alleviating or circumventing the impress of the directives issued forth by 
those in power. 'Processually', any distinction between tactics and strategy blurs even further when being planless by design (Isenberg, 1987: 94) becomes a strategic advantage precisely because it offers no line to attack and no singular message to distort or undermine. In this final section we bring these three ways of conceiving of strategy-tactics distinctions into conversation in order to suggest further research directions in each area.

Pragmatic distinctions have far-reaching and well-documented consequences. They include the recurring problems of implementing or sustaining strategic ideas when faced with the concreteness and immediacy of demands in the here and now as well as the hierarchical separation and prioritization of organizational elites over middle managers and the shop floor, for instance when local concerns about strategic change initiatives are read as acts of 'resistance' that need to be overcome. Those struggling with the consequences of pragmatic distinctions between strategy and tactics can learn from the sociological perspective that it may be the one-sidedness of their preference for all things 'strategic' that lies at the core of many recurring conceptual and practical problems, in particular those relating to the implementation of strategies in organization practice (see Sull, et al., 2015). Here it may be helpful to elevate our appreciation of tactics. Rather than seeing them as merely subordinate processes, tactics can bring about powerful political opposition to directives of strategists and we have identified a well documented set of examples illustrates the efficacy of lobbying tactics (Holburn, et al., 2014), 'strange' idiosyncratic tactical moves (Chang \& Park, 2012), or dissimulating tactics (Sherwood, 1990; Chen \& Hambrick, 1995; Mackay et al., 2013). Crucially, such tactics gain more traction the more they are up against rigidly formalized, abstract and long-term strategies as tactical responses feed off the frictions and rigidities inherent in these. Proponents of pragmatic strategy-tactics distinctions may also gain from the accounts provided by the 'processual' perspective which explicitly acknowledges the brittleness of strategic 'certainties' (Valery, 1962). Von Clausewitz (2007: 89) already cautioned that 'we must remind ourselves that it is simply not possible to construct a model for the art of war that can serve as a scaffolding on which the commander can rely for support 
at any time'; or, expressed in Sull et al.'s (2015: 61) updated version: "no Gantt chart survives contact with reality".

For the pragmatic set of literature, we consequently suggest two directions for further research. First, there is a need to study tactics as important units of organizational analysis. Sociologically inflected contributions take tactics seriously because they are interested in ways of practicing rather than in "any scientific status ... gained through numbers, tables, and percentages" (Certeau, 1998: xx), and in so doing they shed light on concrete situational demands of organizational life. This is not the same as studying strategy-making practices (e.g. Jonson et al., 2003); it includes specifically those actions that are not per se considered to be 'strategic' but instead are reactive, short-term, or contextually and situationally specific, forming the latent background against which any strategically clear formulation can be delineated. Investigating such backgrounds promises to shed light on the 'anthill-like structures' (Certeau, 1998: 3) of activities that make up organizations and the various localized meanings and the rationales for doing things in specific ways. Paying attention to tactics not only helps understand the particularities of a strategic environment, but it may also guard a strategist against the resourcefulness and ingenuity of tacticians who, otherwise, can find near endless ways of subverting or redirecting strategic impulses (Scott, 1998), often merely to elicit further 'strategic' initiatives by the establishment which then equally open up further scope for new forms of resistance or dissimulation (e.g. Kilduff, et al., 2010; Timming, 2007).

Second, we argue for more research into the process of distinction-making entailed when some concerns come to be called strategic and others tactical. We were surprised by the predominance of preference for all things 'strategic' in the literature we reviewed and the relative scarcity of contributions critically engaging with this preference. The strategy-tactics distinction is performative in perpetuating a separation of strategic intelligence from seemingly less-intelligent tactical action; organizational elites from lower echelons; stipulated 
general and long term ends over immediate and specific concerns; and what seems rationally logical over what may feel right or appropriate right here and now (see March, 2003). It is therefore paramount to investigate not just the wider politico-historical conditions that give rise to such a continued one-sidedness but also how everyday decisions and their justifications continually carve out a space for a preferred strategic mode while othering alternative considerations (c.f. Agamben, 2004).

The sociological and processual perspectives provide stimulating cues to question the taken for granted distinction patterns. Yet, at least in their managerial incarnations, more work is needed to flesh out the constructive aspects of these ideas. We have seen how in particular the more mainstream contributions on strategy and tactics are rooted in (and are generative of) the everyday language and understandings of strategists in organizational settings. In contrast, there are only few contemporary organizational illustrations of the sociological and processual alterantives so far. We found instead that authors resorted to military history (Clausewitz, 2007), to everyday practices such as cooking (Certeau, 1998), or to Chinese warfare, poetry and painting (Jullien, 2000, 2004b, 2007) to illustrate that just because tactics may not abide by rational, calculative and abstract notions of 'intelligence', they nonetheless operate according to structures which we can study and understand. What appears to be missing at present is a clearer link of these ideas with contemporary examples of strategic and tactical manoeuvring and other forms of guerrilla warfare in organizational practice (e.g. Pech \& Slade, 2003; McCabe, 2009). Without these links, the rich insights that may be offered by both sociological and processual views face the danger of being side-lined as obscure and arcane. This would be a pity. In a world where modern media affords impactful whistleblowing; where computerized stock exchanges cause chain reactions in response to rumours; where corporate spokespeople are rhetorical experts; and where multinational corporations versed at playing off diverging national regulatory frameworks and interests against each other, the reliance on formal, abstract and long-term strategic intelligence appears at times more antiquated than the bland strategies fostered by ancient Chinese 
strategists. Sociological and processual perspectives may serve as a starting point for a research programme that may not only come to enrich our comprehension of 'real' organizational life, but also help remove some of the artificial and problematic distinctions that separate thinking and doing in managerial practice. 


\section{References}

Agamben, G. (2004). The Open. Stanford. Stanford University Press.

Ählström, J., \& Sjöström, E. (2005). CSOs and business partnerships: strategies for interaction. Business Strategy and the Environment, 14(4), 230-240.

Anand, V., Ashforth, B. E., \& Joshi, M. (2005). Business as usual: The acceptance and perpetuation of corruption in organizations. Academy of Management Executive, 19(4), 9-23.

Anderson, J. C., \& Hoffman, T. R. (1978). A Perspective on the Implementation of Management Science. Academy of Management Review, 3, 563-571.

Angell, I. O. (1990). Systems thinking about information systems and strategies. Journal of InformationTechnology, 5(3), 168-174.

Appelbaum, S., H. , Everard, A., \& Hung, L., T. S. . (1999). Strategic downsizing: critical success factors. Management Decision, 37(7), 535-552.

Augier, M \& Guo, J. (2012) Geopolitics and garbage cans: Understanding the essence of decision making in an interdisciplinary and psycho-cultural perspective. In: Lomi, A. \& Harrison, R.J. The garbage can model of organizational choice: Looking forward at forty. Research in the Sociology of Organizations, Vol. 36: 431- 458.

Bacharach, S. B., Bamberger, P., \& McKinney, V. (2000). Boundary Management Tactics and Logics of Action: The Case of Peer-Support Providers. Administrative Science Quarterly, 45(4), 704-736.

Bacharach, S. B., Bamberger, P., \& Mundell, B. (1995). Strategic and Tactical Logics of Decision Justification: Power and Decision Criteria in Organizations. Human Relations,48(5), 467-488.

Baker III, H. E., \& Feldman, D. C. (1991). Linking Organizational Socialization Tactics with Corporate Human Resource Management Strategies. Human Resource Management Review, 1(3), 193 202.

Baker, T., Miner, A. S., \& Eesley, D. T. (2003). Improvising firms: bricolage, account giving and improvisational competencies in the founding process. Research Policy, 32(2), 255-276.

Bakken, T. (2013) George Spencer Brown, in : Helin, J., Hernes, T., Hjorth, D. \& Holt, R. The Oxford Handbook of Process Philosophy and Organization Studies. Oxford. Oxford University Press: 481498.

Bakken, T. \& Hernes, T. (2006) Organizing is both a verb and a noun: Weick meets Whitehead. Organization Studies, 27(11): 1599-1616.

Bakken, T. and Holt, R. and Zundel, M. (2013) Time and play in management practice: An investigation through the philosophies of McTaggart and Heidegger. Scandinavian Journal of Management, 29 (1). pp. 13-22.

Barney, J. (2002). Gaining and Sustaining Competitive Advantage. Engelwood Cliffs, NJ: Prentice Hall. 
Barron, A. (2010). Unlocking the mindsets of Government Affairs Managers. Cross Cultural Management, 17(2), 101-117.

Bauman, Z. (2007) Consuming life. London: Wiley.

Bell, J. A., \& Keusch, R. B. (1976). Comprehensive Planning for Libraries. Long Range Planning, 9(5), 48-56.

Brodie, B. (1959) Strategy in the missile age. Princeton. Princeton University Press.

Bush, D., \& Gelb, B. D. (2005). When Marketing Practices Raise Antitrust Concerns. MIT Sloan Management Review, 46(4), 73-81.

Buskirk, R., H. (1976). Handbook of Managerial Tactics. Boston: Cahners Books International, Inc.

Capron, L., \& Mitchell, W. (2010). Finding the Right Path. Harvard Business Review, 88(7/8), 102107.

Carmeli, A., \& Markman, G. D. (2011). Capture, governance, and resilience: strategy implications from the history of Rome. Strategic Management Journal, 32(3), 322-341.

Carter, C. (2013) The age of strategy: Strategy, organizations and society. Business History, 55(7): 1047-1057.

Casadesus-Masanell, R., \& Ricart, J. E. (2010).From Strategy to Business Models and onto Tactics. Long Range Planning, 43(2/3), 195-215.

Chaffee, E.E. (1985) Three Models of Strategy. Academy of Management Review, 10(1): 89-95.

Chang, S-J. \& Park, S.H. (2012) Winning strategies in China: Competitive dynamics between MNCs and local firms. Long Range Planning, 45: 1-15.

Chattopadhyay, P., Glick, W.H., Miller C.C. * Huber, G.P. (1999) Determinants of executive beliefs: Comparing functional conditioning and social influence. Strategic Management Journal, 20: 763-789.

Chen, M.J. \& Hambrick, D.C. (1995) Speed stealth and selective attack: how small firms differ from large firms in competitive behavior. Academy of Management Journal 38: 453-482.

Chia, R., C. H., \& Holt, R. (2009). Strategy Without Design: The Silent Efficacy of Indirect Action. Cambridge: Cambridge University Press.

Child, J. (1997). Strategic change in the analysis of action, structures, organisation and environment retrospect and prospect. Organization Studies, 18(1), 43-76.

Churchman, C. W., \& Schainblatt, A. H. (1965). The Research and the Manager: A Dialectic of Implementation. Management Science, 11(4), B69-87.

Clarke, C. J., \& Varma, S. (1999). Strategic Risk Management: the New Competitive Edge. Long Range Planning, 32(4), 414-424. 
Clegg, S., Carter, C., Kornberger, M., \& Schweitzer, J. (2011). Strategy: Theory and Practice. London: Sage.

Clougherty, J.A. (2005) Antitrust holdup source, cross-national institutional variation, and corporate political strategy implications for domestic mergers in a global context. Strategic Management Journal, 26: 769-790.

Connelly, B. L., Tihanyi, L., Certo, S. T., \& Hitt, M. A. (2010). Marching to the Beat of Different Drummers: The Influence of Institutional Owners on Competitive Actions. Academy of Management Journal, 53(4), 723-742.

Cooper, R. (1986). Organization/Disorganization. Social Science Information, 25(2), 299-335.

Cornut, F., Giroux, H. \& Langley, A. (2012) The strategic plan as a genre. Discourse and Communication, 6(1): 21-54.

Covin, J. G., Slevin, D. P., \& Schultz, R. L. (1994). Implementing Strategic Missions: Effective Strategic, Structural and Tactical Choices. Journal of Management Studies, 31(4), 481-506.

Cross, R. G., Higbie, J. A., \& Cross, D. Q. (2009). Revenue Management's Renaissance. Cornell Hospitality Quarterly, 50(1), 56-81.

Cumming, S. \& Dellenbach, U. (2009) A Guide to the Futrue of Strategy: The History of Long Range Planning. Long Range Planning 42: 234-263.

Cutcher, L. (2009). Resisting change from within and without the organization. Journal of Organizational Change Management, 22(3), 275-289.

Dahlander, L., \& Magnusson, M. (2008). How do Firms Make Use of Open Source Communities? Long Range Planning, 41(6), 629-649.

De Certeau, M. (1988). The Practice of Everyday Life (1st ed.). Berkeley: University of California Press.

De Certeau, M. (1998) The Practice of Everyday life. Vol: 2: Living and Cooking. London: University of Minnesota Press.

Denis, J.-L., Langley, A., \& Cazale, L. (1996). Leadership and Strategic Change Under Ambiguity. Organization Studies, 17(4), 673-699.

Dibb, S., \& Simkin, L. (1993). Strategy and tactics: Marketing leisure facilities. The Service Industries Journal, 13(3), 110-124.

Dick, P. \& Collings, D.G. (2014) Discipline and Punish? Strategy Discourse, Senior Manager subjectivity and Contradictory Power Effects. Human Relations (published online ahead of press).

Dinwoodie, J., Tuck, S., Knowles, H., Benhin, J., \& Sansom, M. (2012). Sustainable Development of Maritime Operations in Ports. Business Strategy and the Environment, 21(2), 111-126.

Donaldson, G. (1972). Strategic hurdle rates for capital investment. Harvard Business Review, 50(2), $50-58$. 
Doyle, P. (1977). Long Range Planning and Advertising. Long Range Planning, 10(6), 16-22.

Durham, C. C., Knight, D., \& Locke, E. A. (1997). Effects of leader role, team-set goal difficulty, efficacy, and tactics on team effectiveness. Organizational Behavior and Human Decision Processes, 72(2), 203-231.

Easingwood, C., \& Harrington, S. (2002). Launching and re-launching high technology products. Technovation, 22(11), 657-666.

Eisenhardt, K. M. (1989). Making Fast Strategic Decisions In High-Velocity Environments. Academy of Management Journal, 32(3), 543-576.

Eisenhardt, K. M. (1990). Speed and Strategic Choice: How Managers Accelerate Decision Making. California Management Review, 32(3), 39-54.

Elsbach, K. D., \& Sutton, R. I. (1992). Acquiring Organizational Legitimacy Through Illegitimate Actions: A Marriage of Institutional and Impression Management Theories. Academy of Management Journal, 35(4), 699-738.

Freedman, L. (2013) Strategy: A History. Oxford. Oxford University Press.

Gabriel, Y. (2002). Essal: On Paragrammatic Uses of Organizational Theory -- A Provocation. Organization Studies, 23(1), 133-151.

Graffin, S.D., Carpenter, M.A. \& Boivie, S. (2011) What's all that (strategic) noise? Anticipatory impression management in CEO succession. Strategic Management Journal, 32: 748-770.

Ghemawat, P., \& Levinthal, D. (2008). Choice Interactions and Business Strategy. Management Science, 54(9), 1638-1651.

Gibson, R. E. (1966). The Strategy of Corporate Research and Development. California Management Review, 9(1), 33-42.

Giles, W. D. (1991). Making Strategy Work. Long Range Planning, 24(5), 75-91.

Goldman, J. E. (2001). Ten ways to shake the corporate world. Research Technology Management, 44(2), 9-12.

Gray, C.S. (2006) History and Strategy. Oxon, Routledge.

Gray, B., \& Ariss, S. S. (1985). Politics and Strategic Change Across Organizational Life Cycles. Academy of Management Review, 10(4), 707-723.

Greenley, G. E. (1983). Tactical Product Decisions. Industrial Marketing Management, 12(1), 13-18.

Gronroos, C. (1996). Relationship marketing: Strategic and tactical implications. Management Decision, 34(3), 5-14.

Guiltinan, J. P. (1999). Launch Strategy, Launch Tactics, and Demand Outcomes. Journal of Product Innovation Management, 16(6), 509-529. 
Hambrick, D. C., \& Cannella Jr, A. A. (1989). Strategy Implementation as Substance and Selling. Academy of Management Executive, 3 (4), 278-285.

Hamel, G. (2007). The Future of Management. Boston: Harvard Business School Press.

Hamel, G. (2012). What Matters Now. San Francisco: Jossey-Bass.

Hamel, G., \& Välikangas, L. (2003). The Quest for Resilience. Harvard Business Review, 81(9), 52-63.

Harris, L. C. (2000). Getting Professionals to Plan: Pressures, Obstacles and Tactical Responses. Long Range Planning, 33(6), 849-877.

Herepath, A. (2014) In the Loop: A Realist Approach to Structure and Agency in the Practice of Strategy. OrganizationStudies 35(6): 857-879.

Herman, P. \& Nadkarni, S. (2014) Managing strategic change: The duality of CEO personality. Strategic Management Journal, 35: 1318-1342.

Hjorth, D. (2005). Organizational Entrepreneurship: With de Certeau on Creating Heterotopias (or Spaces for Play). Journal of Management Inquiry, 14(4), 386-398.

Hjorth, D. (2007) Lessons from Iago: Narrating the event of entrepreneurship. Journal of Business Venturing 22: 712-732.

Holburn, G.L.F., Richard, G. \& Bergh, V. (2014) Integrated market and nonmarket strategies: Political campaign contributions around merger and acquisition events in the energy sector. Strategic Management Journal, 35: 450-460.

Hultink, E. J., Griffin, A., Hart, S., \& Robben, H. S. J. (1997). Industrial New Product Launch Strategies and Product Development Performance. Journal of Product Innovation Management, 14(4), 243-257.

Huntsman, S. (1994). Using Strategic Planning to Drive Organizational Change. Long Range Planning, 27(1), 50-55.

Isenberg, D. J. (1987). The tactics of strategic opportunism. Harvard Business Review, 65(2), 92-97.

Jacobs, J. (1993) The death and life of great American cities. New York. Random House

Jantsch, E. (1968). Technological Forecasting in Corporate Planning. Long Range Planning, 1(1), 4050 .

Jarzabkowski, P., \& Spee, P. A. (2009). Strategy-as-practice: A review and future directions for the field. International Journal of Management Reviews, 11(1), 69.

Johnson, G., Langley, A., Melin, L., \& Whittington, R. (2008). Strategy as Practice- Research Directions and Resources (1st ed.). Cambridge: Cambridge University Press.

Judge, T. A., \& Bretz, R. D. (1994). Political Influence Behavior and Career Success. Journal of Management, 20(1), 43-65. 
Jullien, F. (2000). Detour and Access: Strategies of Meaning in China and Greece (S. Hawkes, Trans.). New York: Zone Books.

Jullien, F. (2004a). A Treatise on Efficacy - Between Western and Chinese Thinking (J. Lloyd, Trans.). Honolulu: University of Hawai'i Press.

Jullien, F. (2004b). In Praise of Blandness: Proceeding from Chinese Thought and Aesthetics (P. M. Varsano, Trans.). New York: Zone Books.

Jullien, F. (2007). Vital Nourishment: Departing from Happiness (A. Goldhammer, Trans.). New York: Zone Books.

Jullien, F. (2011). The Silent Transformations (K. Fijalkowski \& M. Richardson, Trans. 1st ed.). Calcutta: Seagull Books.

Kay, J., McKiernan, D. \& Faulkner D.O. (2006) The History of Strategy and some Thoughts about its Future. In The Oxford Handbook of Strategy: A Strategy Overview and Competitive Strategy. A. Campbell and D. O. Faulkner (eds). Oxford: Oxford University Press.

Keys, B., \& Case, T. (1990). How to become an influential manager. Academy of Management Executive, 4(4), 38-51.

Kharbanda, O. P., \& Stallworthy, E. A. (1991). Negotiation: An Essential Management Skill. Journal of Managerial Psychology, 6(4), 2-52.

Kilduff, M., Chiaburu, D. S., \& Menges, J. I. (2010). Strategic use of emotional intelligence in organizational settings: Exploring the dark side. Research in Organizational Behavior, 30, 129-152.

Kimes, S. E., \& Singh, S. (2009). Spa Revenue Management. Cornell Hospitality Quarterly, 50(1), $82-$ 95.

Kornberger, M. (2013) Disciplining the Future: On Studying the Politics of Strategy. Scandinavian Journal of Management, 29(1): 104-107.

Knights, D. (1992) Changing spaces: The disruptive impact of an new epistemological location for the study of management. Academy of Management Review, 17(3): 514-536.

Knights, D. \& Morgan, G. (1990) The Concept of Strategy in Sociology: A Note of Dissent. Sociology 24(3): 475-483.

Knights, D. \& Morgan, G. (1991) Corporate Strategy, Organizations, and Subjectivity: A Critique. Organization Studies 12(2): 251-273.

Kolb, D. M. (1983). Strategy and the Tactics of Mediation. Human Relations, 36(3), 247-247.

Kreutzer, M., Walter, J. \& Cardinal, L.B. (2014) Organizational control as antidote to politics in the pursuit of strategic initiatives. Strategic Management Journal, online first.

La Londe, B. J., \& Headen, R. (1971). Strategic Planning for Distribution. Long Range Planning, 4(2), 23-29. 
Lake, N. (2004). The Real Art of Strategic Planning. Total Quality Management \& Business

Excellence, 15(5/6), 735-742.

Lant, T. K., \& Hewlin, P. F. (2002). Information Cues and Decision Making: The Effects of Learning, Momentum, and SocialComparison in Competing Teams. Group \& Organization Management, 27(3), 374-407.

Lax, D. A., \& Sebenius, J. K. (2012). Deal Making 2.0: A Guide to Complex Negotiations. Harvard Business Review, 90(11), 92-100.

Lee, R. (2009). Social capital and business and management: Setting a research agenda. International Journal of Management Reviews, 11(3), 247-273.

Lilien, G. L., \& Rao, A. G. (1979). Emerging Approaches to Retail Outlet Management. Sloan Management Review, 20(2), 27-36.

Lovell, R. J. (1993). Power and the project manager. International Journal of Project Management, 11(2), 73-78.

Lueger, M., Sandner, K., Meyer, R., \& Hammerschmid, G. (2005). Contextualizing Influence Activities: An Objective Hermeneutical Approach. Organization Studies 26(8), 1145-1168.

Macario, R. (2001). Upgrading quality in urban mobility systems. Managing Service Quality, 11(2), 93-99.

Mackay, D., Zundel, M. \& Alkirwi, M. (2014) Exploring the practical wisdom of metis for management learning. Management Learning, 45 (4), 418-436.

Macpherson, A., \& Jones, O. (2010). Editorial: Strategies for the Development of International Journal of Management Reviews. International Journal of Management Reviews, 12(2), 107-113.

Mahmoud, S. (1975). The E.P.R.G. Schema and Multinational Management: A Perspective of Employment Practices. Journal of Management, 1(1), 25-30.

March, J.G. (2003) A scholar's quest. Journal of Management Inquiry, 12: 205-209.

March, J. G. (2006). Rationality, foolishness, and adaptive intelligence. Strategic Management Journal, 27(3), 201-214.

Markides, C. C., \& Berg, N. A. (1992). Good and Bad Divestment: The Stock Market Verdict. Long Range Planning, 25(2), 10-15.

Massetti, B., \& Zmud, R. W. (1996). Measuring the extent of EDI usage in complex organizations: Strategies and illustrative examples. MIS Quarterly, 20(3), 331-345.

McCabe, D. (2009) Strategy-as-power: Ambiguity, contradiction and the exercise of power in a UK building society. Organization 17(2): 151-175.

McInlay, A., Carter, C., Pezet, E. \& Clegg, S. (2010) "Using Foucault to make strategy", Accounting, Auditing \& Accountability Journal, 23 (8), pp.1012 - 1031 
McNamara, G.M., Haleblian, J. \& Johnson Dykes, B. (2008) The performance implications of participating in an acquisition wave: Early mover advantages, bandwagon effects, and the moderating influence of industry characteristics and acquirer tactics. Academy of Management Journal, 51(1): 113130.

Meijboom, B., \& Obel, B. (2007). Tactical coordination in a multi-location and multi-stage operations structure: A model and a pharmaceutical company case. Omega, 35(3), 258-273.

Micheli, P., \& Manzoni, J.-F. (2010). Strategic Performance Measurement: Benefits, Limitations and Paradoxes. Long Range Planning, 43(4), 465-476.

Miller, C. C., \& Ireland, R. D. (2005). Intuition in strategic decision making: Friend or foe in the fastpaced 21st century? Academy of Management Executive, 19(1), 19-30.

Mintzberg, H., \& Waters, J. A. (1985). Of Strategies, Deliberate and Emergent. Strategic Management Journal, 6(3), 257-272.

Munro, I. (2005). Information warfare in business: Strategies of resistance and control in the network society. London: Routledge.

Munro, I. (2010). Nomadic strategies in the network society: From Lawrence of Arabia to Linux. Scandinavian Journal of Management, 26(2), 215-223.

Nag, R., Hambrick, D.C., \& Chen, M.-J. (2007) What is Strategic Management Really? Inductive Derivation of a Consensus Definition of the Field. Strategic Management Journal, 28: 935-956.

Nollet, J., Rebolledo, C., \& Popel, V. (2012). Becoming a preferred customer one step at a time. Industrial Marketing Management, 41(8), 1186-1193.

Nonaka, I., Chia, R., Holt, R. \& Peltokorpi, V. (2014) Wisdom, management and organization. Management Learning, 45(4), 365-376.

Nussbaum M (1986) The Fragility of Goodness. Cambridge: Cambridge University Press.

Nutt, P. C. (1986). Tactics of Implementation. Academy of Management Journal, 29(2), 230-261.

Nutt, P. C. (1987). Identifying and Appraising How Managers Install Strategy. Strategic Management Journal, 8(1), 1-14.

Nutt, P. C. (1989). Selecting Tactics To Implement Strategic Plans. Strategic Management Journal, 10(2), 145-161.

Nutt, P. C. (1993). The Identification of Solution Ideas During Organizational Decision Making. Management Science, 39(9), 1071-1085.

Nutt, P. C. (1998a). Evaluating alternatives to make strategic choices. Omega, 26(3), 333.

Nutt, P. C. (1998b). How Decision Makers Evaluate Alternatives and the Influence of Complexity. Management Science, 44(8), 1148-1166. 
Nutt, P. C. (1999). Surprising but true: Half the decisionsin organizations fail. Academy of Management Executive, 13(4), 75-90.

Nutt, P. C. (2002). Why Decisions Fail: San Francisco: Berrett-Koehler Publishers.

Nutt, P. C. (2004). Expanding the search for alternatives during strategic decision-making. Academy of Management Executive, 18(4), 13-28.

Nutt, P. C. (2008). Investigating the Success of Decision Making Processes. Journal of Management Studies, 45(2), 425-455.

Oliver, C. (1991) Strategic Responses to Institutional Processes. Academy of Management Review, 16(1), 145-179.

Okumus, F. (2004). Implementation of Yield Management Practices in Service Organizations: Empirical Findings from a Major Hotel Group. The Service Industries Journal, 24(6), 65-89.

Page, S. (2010). Integrative leadership for collaborative governance: Civic engagement in Seattle. Leadership Quarterly, 21(2), 246-263.

Paquette, L. (1991) Strategy and Time in von Clausewitz's Vom Kriege and Sun Tzu's The Art of War. Comparative Strategy, 10, 37-51.

Pauchant, T. C., Mitroff, I. I., \& Ventolo, G. F. (1992). The dial tone does not come from God! how a crisis can challenge dangerous strategic assumptions made about high technologies: the case of the hinsdale telecommunication outage. Academy of Management Executive, 6(3), 66-79.

Pech, R. J., \& Slade, B. W. (2003). Asymmetric competition: decision processes shaping the future. Management Decision, 41(9), 883-892.

Peters, J. (1993). On objectives. Management Decision, 31(6), 28-30.

Pfeffer, J. (1992). Understanding Power in Organizations. California Management Review, 34(2), 2950.

Pinto, J. K., \& Prescott, J. E. (1990). Planning and Tactical Factors in the Project Implementation Process. Journal of Management Studies, 27(3), 305-327.

Porter, M. E. (1996). What Is Strategy? Harvard Business Review, 74(6), 61-78.

Priem, R.L., Butler, J.E. \& Li, S. (2011) Toward Reimagining Strategy Research: Retrospection and Prospection on the 2011 AMR Decade Award Article. Academy of Management Review, 39(4): 471489.

Ramanath, R., \& Ebrahim, A. (2010). Strategies and tactics in NGO-government relations: Insights from slum housing in Mumbai. Nonprofit Management and Leadership, 21(1), 21-42.

Rangan, V. K., \& Jaikumar, R. (1991). Integrating Distribution Strategy and Tactics: A model and an Application. Management Science, 37(11), 1377-1389. 
Raturi, A. S., Meredith, J. R., McCutcheon, D. M., \& Camm, J. D. (1990). Coping with the Build-toForecast Environment. Journal of Operations Management, 9(2), 230-249.

Sherwood RM. 1990. Intellectual Property and Economic Development. Westview Press: Boulder, CO.

Smith A.,Watkins, M.B., Burke, M.J., Christian, M.S., Smith, C.E., Hall, A., Simms, S. (2013)

Influence as gendered strategy: a meta-analytic reviewon the impact of gender status on influence effectiveness. Journal of Management 35(5): 1156-1183.

Stevens, C.E., Xie, E., \& Peng, M.W. (2015) Toward a legitimacy-based view of political risk: the case of Google and Yahoo in China Strategic Management Journal. Online first.

Sull, D; Homkes, R., \& Sull, C (2015) Why Strategy Execution Unravels - and What to Do About It. Harvard Business Review, March :58-66.

Suominen, K., \& Mantere, S. (2010). Consuming strategy: The art and practice of managers' everyday strategy usage In J.A.C. Baum \& J. Lampel (Eds), The Globalization of Strategy Research. Advances in Strategic Management. Vol. 27, pp. 211-245, Bingley: Emerald

Tepper, B. J. (1995). Upward Maintenance Tactics in Supervisory Mentoring and Nonmentoring Relationships. Academy of Management Journal, 38(4), 1191-1205.

Timming, A. R. (2007). European Works Councils and the dark side of managing worker voice. Human Resource Management Journal, 17(3), 248-264.

Trachtenberg, M. (1989) Strategic thought in America, 1952-1966. Political Science Quarterly, 104(2): 301-334.

Tranfield, D., Denyer, D., \& Smart, P. (2003). Towards a methodology for developing evidenceinformed management knowledge by means of systematic review. British Journal of Management, 14(3), 207-222.

Vaara, E. (2010). Taking the linguistic turn seriously: Strategy as A multifaceted and interdiscursive phenomenon In J.A.C. Baum \& J. Lampel (Eds), The Globalization of Strategy Research. Advances in Strategic Management. Vol. 27, pp. 29-50. Bingley: Emerald

Vaara, E., \& Whittington, R. (2012). Strategy-as-Practice: Taking Social Practices Seriously. Academy of Management Annals, 6(1), 285-336.

Valery, P. (1962) The outlook for intelligence. Bollington Series XLV10. Trans. D. Folliot \& J. Mathews. Princeton: Princeton University Press.

Van Wingerden, R. G. (2001). Managing change. International Journal of Technology Management, 21(5,6), 487-495.

von Clausewitz, C. (2007). On War (M. Howard \& P. Paret, Trans.). Oxford: Oxford University Press.

Vredenburgh, D. J., \& Maurer, J. G. (1984). A Process Framework of Organizational Politics. Human Relations, 37(1), 47-65.

Watkins, M.B., Smith, A.N., Aquino, K. (2013) Sexual influence: the use and consequences of strategic sexual performances. Academy of Management Perspectives 27(3): 173-186. 
Westphal, J. D., \& Bednar, M. K. (2008). The Pacification of Institutional Investors. Administrative Science Quarterly, 53(1), 29-72.

Whittingtoon, R. 2004. Strategy after modernism: recovering practice. European Management Review, 1, 62-68.

Yaziji, M., \& Doh, J. P. (2013). The Role of Ideological Radicalism and Resource Homogeneity in Social Movement Organization Campaigns against Corporations. Organization Studies, 34(5/6), 755780. 


\begin{tabular}{|c|c|c|c|}
\hline & Pragmatic & Sociological & Processual \\
\hline $\begin{array}{l}\text { Understanding } \\
\text { of strategy }\end{array}$ & $\begin{array}{l}\text { Guided by reason - } \\
\text { overcoming immediate } \\
\text { requirements/stimuli for } \\
\text { response }\end{array}$ & $\begin{array}{l}\text { Organization of social } \\
\text { relations. Indicative of a } \\
\text { multiplicity of strategic } \\
\text { sources and positions } \\
\text { that dynamically evolve. }\end{array}$ & \multirow[t]{2}{*}{$\begin{array}{l}\text { No fixed distinction } \\
\text { between strategy and } \\
\text { tactics. Continuous } \\
\text { renegotiation of } \\
\text { boundaries as the } \\
\text { situation demands. }\end{array}$} \\
\hline $\begin{array}{l}\text { Understanding } \\
\text { of tactics }\end{array}$ & $\begin{array}{l}\text { Immediate and executed } \\
\text { under guidance of strategy. } \\
\text { Usually relegated to lower } \\
\text { levels of hierarchy }\end{array}$ & $\begin{array}{l}\text { Possibility of dealing } \\
\text { with others' attempts at } \\
\text { being organized. }\end{array}$ & \\
\hline $\begin{array}{l}\text { Relationship } \\
\text { between } \\
\text { strategy and } \\
\text { tactics }\end{array}$ & $\begin{array}{l}\text { Various pragmatic } \\
\text { distinctions, e.g. long and } \\
\text { short term horizons; } \\
\text { involvement of upper or } \\
\text { lower hierarchical levels; } \\
\text { general or local impact. } \\
\text { Difference is largely a } \\
\text { matter of degree. }\end{array}$ & $\begin{array}{l}\text { Oppositional but } \\
\text { mutually constitutive. } \\
\text { Greater strategic } \\
\text { positions of power } \\
\text { require (and sometimes } \\
\text { give rise to) greater need } \\
\text { for tactical responses or } \\
\text { resistance. }\end{array}$ & $\begin{array}{l}\text { Interchangeable and } \\
\text { fluid. Ceaseless } \\
\text { movement between } \\
\text { positions. }\end{array}$ \\
\hline Preference & $\begin{array}{l}\text { Preference for strategy - at } \\
\text { the extreme end to replace } \\
\text { (or render unnecessary) } \\
\text { tactics altogether }\end{array}$ & $\begin{array}{l}\text { Balanced, as both modes } \\
\text { are interdependent. } \\
\text { Studies may either give } \\
\text { preference to strategy } \\
\text { (eg. Agency theory) or to } \\
\text { tactics (e.g Certeau). }\end{array}$ & $\begin{array}{l}\text { Preferencing rejected } \\
\text { - strategy and tactics } \\
\text { treated as irreducible, } \\
\text { parallel concepts that } \\
\text { need to be explored } \\
\text { in combination }\end{array}$ \\
\hline Problems & $\begin{array}{l}\text { Difficulty of defining } \\
\text { boundaries between } \\
\text { strategic and tactical } \\
\text { realms } \\
\text { Ideal and rational } \\
\text { strategies run against } \\
\text { messy tactical realities }\end{array}$ & $\begin{array}{l}\text { No position can be held } \\
\text { for long; demands on } \\
\text { securing; tactics may } \\
\text { turn into proper places. }\end{array}$ & $\begin{array}{l}\text { Difficult to sustain; } \\
\text { impossible to fortify } \\
\text { positions; } \\
\text { uncomfortable if not } \\
\text { irrational and may be } \\
\text { perceived to be } \\
\text { esoteric. }\end{array}$ \\
\hline
\end{tabular}

$\underline{\text { Table } 1 \text { - Summary of main strategy-tactics distinctions }}$ 


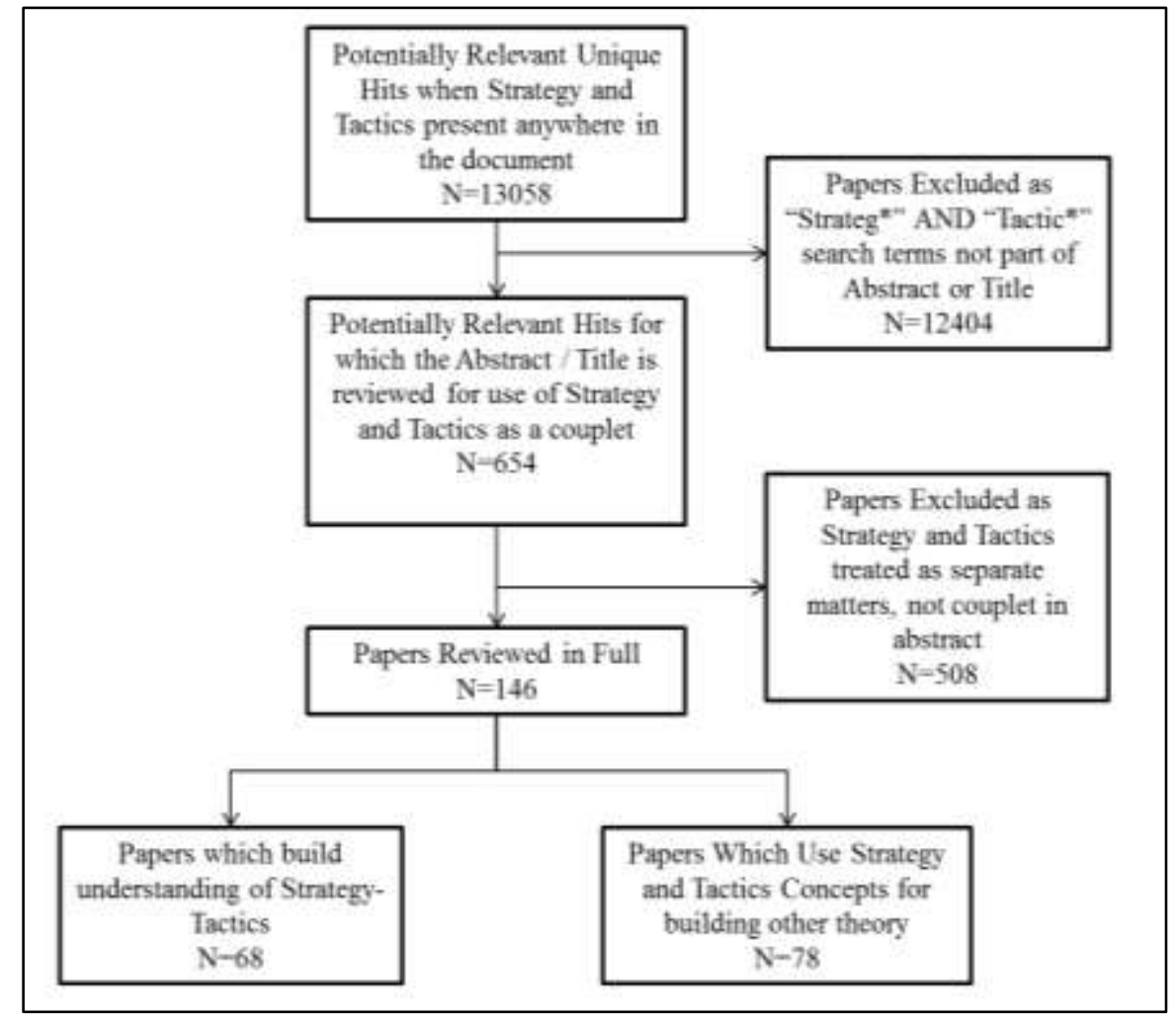

Figure 1 -Summary of Paper Selection Process 